\title{
Investigating the vertical displacement of Duhok embankment Dam: A 31 - Years Case Study
}

\author{
Sarmad Abdullah M.Salim* and Sarhat Mustafa Adam \\ * College of Engineering, University of Duhok, Iraq. \\ *Email: Sarmad.m.salim@uod.ac; Corresponding Author.
}

\begin{abstract}
The paper studies the long-term settlement behaviour of more than 30-year of the Duhok dam. The dam uses as the major lake for water supply to the city of Duhok and nearby areas. Highprecision levelling was used to measure the deformation of the dam to monitor vertical displacements. Five survey campaigns were conducted over 30-year duration: 1988, March 1990, June 1999, March 2017 and February 2019. Analysis of the results found that the highest downward displacement of roughly $20.4 \mathrm{~cm}$ was witnessed between 1988 and 2019 for a monitoring point (BM24) located centrally along the bank of the dam. On the other hand, the highest vertical movement of roughly $1.5 \mathrm{~cm}$ was estimated between 1990 and 2019 at the monitoring point (BM27) on the west side of the dam. The monitoring point (BM24) had the highest average absolute movement of about $6.0 \mathrm{~mm}$ (per year) over the 31 years. Detailed results and analyzes are presented in this article.
\end{abstract}

Key words: Duhok dam; deformation monitoring; precise levelling; vertical displacement

\section{INTRODUCTION}

The surface of the planet is not at rest but slowly changes, probably due to several factors such as man-made structures and Earth's nature itself. Hence, it is necessary to be alert about the engineering structures' motions which serve human existence. Most deformation monitoring 
studies analyse various types of engineering structures such as dams, bridges, tall buildings or infrastructures, tunnels, manufacturing subdivisions, etc. The measuring methods use for performing the analysis differ which are either geodetic or non-geodetic. The selection of proper method depends mainly on the type of structure to be observed, the predicted accuracy of the observations and their environmental factors. As previously stated about possible motions, one reason could attribute to the volcanic explosion, which falls down a sloping rock layer, eventually triggering land subsidence. Other reasons may attribute to the rise in the groundwater level that can react to the consolidation of intersecting soil layers; soil oxidation and drainage; decay and failure of sensitive stones; tectonic and tidal natural events; etc. Most of the main consequences of subsurface movement are a decrease in freeboard level causing reduced flood control; gradient varies across channels of water transport, and breakdown of engineering structures (Richardus, 1977).

Examining the deformation of engineering structures such as dams, viaducts, bridges, towers, etc. is an exceptional challenge for geodesists. Deformation of structures can be measured using different techniques that are commonly categorised into two types: (i) geodetic surveys and (ii) geotechnical technique. Geodetic surveys include conventional measurement techniques such as terrestrial, which involves angle and distance observations, precise measurement with the levelling instrument. The geodetic survey can also include photogrammetry (terrestrial and aerial photogrammetry), satellite (such as Interferometric Synthetic Aperture Radar (InSAR), or Global Positioning System (GPS)) and several other specific methods. Conversely, geotechnical or non-geodetic measurements carried out via 3 tiltmeters, lasers, joint meters, micrometers, plumb-lines, strainmeters, etc. Any method of measurement has its pros and cons. In general, geodetic methods have sufficient redundant measurements that involves in the statistical analysis. The redundant data can help in improving the accuracy and identifying of possible errors which are observed via a network of points linked by direction and/or length. It provides details of the deformable structure's behaviour as compared with some other independent measurements. On the other hand, Nongeodetic techniques i.e. Geotechnical techniques provide spatial and geographically disrupted 
information without any survey. However, equipment that is used for non-geodetic measurements is better to handle for automated as well as repeatable tracking than traditional geodetic measurement devices. Traditionally, geodetic instruments were used mostly to measure the absolute deformations of chosen points on the surface of the structure in relation to other reference points which are considered to be stable. Non-geodetic methods, usually used for estimating relative displacements in the deformable structure (US Army Crops of Engineers, 2002).

Recently, surveys of surface displacement at unstable areas have focused on horizontal deformation determined by GPS. The focus on horizontal deformation is due to inadequate precision using GPS in determining vertical deformation (Verdonck, 2004). This is due to the fact that the height component is always the least accurately measured GPS coordinate, mainly because of intrinsic geometric deficiency as well as atmospheric errors (Çelik et al., 2001; Featherstone, Dentith, \& Kirby, 1998). Due to the limitation of GPS in measuring the vertical displacement, levelling instrument can be used as an essential method for measuring such deformation (Taşçi, 2008).

In literature, various instruments and procedures for the monitoring of dam's behaviour have been developed that are mostly based on geodetic research. For instance, Gikas and Sakellariou (2008) did a comparison between actual observed deformations due to continuous geodetic monitoring and data recorded with a simulated back analysis of Mornos dam behaviour. Their research tried to explain the real history of deformation on the basis of the dam's mechanical behaviour. In their study, they focused on the vertical shifts, in addition to geodetic data covered a cumulative 30-year duration. The results of the geodetic monitoring analysis in their study have been compared with the observations of the finite element study simulating distinctive steps in the lifespan of the structure. Their study concluded a significant correlation (on average $0.03 \mathrm{~m}$ ) between the measured and computed deformations. In a study by Guler, Kilic, Hosbas, and Ozaydin (2006) based on geodetic and geotechnical techniques, analysis of the surface shifts that occurred after construction of an earth-filled dam were evaluated. Using the Karlsruhe method, horizontal and vertical observations of movement 
collected between 1987-1991 and 1991-1996 were geodetically analysed. Similarly, the dam's behaviour and its base layers were checked using the finite element method (FEM) to determine the deformation. The results of the geodetic observations were compared to the numerical analysis, and a high correlation between the field data and the computed measurement values was noted. Research by Kalkan, Potts, and Bilgi (2016) shows the efforts and results of the geodetic measurements of Atatürk dam, the largest volume structure in Turkey and the world's ninth largest dam. Geodetic techniques have been used to estimate potential deformations in the structure and also to add insight into the vital dam safety. The geodetic technique involved differential, trigonometric GPS observation, and leveling campaigns over a period of six and a half years. The results indicate that the crest settlement reached about 30 centimeters close to the river's center which was the highest value. The downstream part of the dam crest seems more rigid, with vertical motion at low amplitudes (< 10 centimeters).

Empirical models have been used to estimate earth-filled dam deformation patterns. Generally, empirical predicted post-construction deformation methods are derived from the analysis of historical deformations. Under normal circumstances, approximately $2 \%$ of the structure height can be considered as allowable settlement of a dam affected by the settlement of its body. Due to the earthquake impact, $1 \%$ is added to this amount in earthquake-prone regions (Dascal \& Oscar, 1987). Estimation of settlement after construction is therefore required to monitor dam stability and to inform design engineers of any safety issue. Paying attention to settlement issues is of extreme significance when the settlement reaches the allowable value. Thus, predicting the settlement of dams is extremely important.

This paper aims to show the vertical deformation analysis of monitoring points of Duhok dam which cover a 31-year period. Another aim of this study is to compare the actual value with predicted value of settlement derived from theoretical background. Outcomes of the analysis clearly show that more than $95 \%$ of the monitoring points surveyed between 1988 and 2019 were shifted downwards, with the maximum displacement of $20.4 \mathrm{~cm}$ at a point called BM24 nearly centrally located along the dam embankment. However, more than $6 \%$ of the crest 
benchmarks were moved upward (uplifted) with the greatest movement of $15.6 \mathrm{~mm}$ recorded within the same period at BM27.

\section{BACKGROUND OF DUHOK DAM}

Embankment dams, that constitute the most common form of dam construction in Iraq and around the world according to the International Commission on Large Dams (ICOLD), may, in turn, be earth-filled dams or rock-filled dams, depending on the prevalent material used. The first mostly compacted soil whereas the second mostly contained coarser material such as gravel and crushed rocks.

Duhok dam is an embankment dam located at the north of Duhok city near Duhok valley, 2 $\mathrm{km}$ far from the centre of the city. The lake is formed by Sindor and Germava rivers. Construction of the dam with all parts started in 1980 and finished in 1988.The dam is $613 \mathrm{~m}$ long and the height of the dam is about $60 \mathrm{~m}$. The crest elevation of the dam is around $620 \mathrm{~m}$ a.s.1 which can store (52 million $\mathrm{m} 3$ ) of water, see figure 1.The main purpose of Duhok dam is to store and save the water of snow and rainfall in both winter and spring seasons to irrigate about $27 \mathrm{~km} 2$ of agricultural land down the dam areas in the summer season. Duhok Dam plays an important role in the water supply for domestic and industrial use during shortage times. Moreover, the dam used for fishing purposes and as a resort area (Tovî \& Șāliḥ, 2017). For any dam, deformation is inevitable (Wang, Perissin, Rocca, \& Liao, 2011). Due to the weight of the structure, the dams are deformed by vertical subsidence and also the horizontal motions perpendicular to the centerline of the dam due to the hydrostatic pressure induced by the water (Gökalp \& Taşç1, 2009). The deformation includes many factors, such as water pressure and friction, building conditions, temperature fluctuations and the foundation's geological characteristics (Emadali, Motagh, \& Haghighi, 2017).

Deformation begins to occur in embankment dams during the construction phase due to an increase in effective stress between the various areas of the dam, then deformation increases in the first fillings of the reservoir, and then the incidence decreases in the long term (Michalis, Pytharouli, \& Raftopoulos, 2016). The magnitude and direction of the displacement change at a particular point in the dam or crest during the various phases of the dam's life. The 
differences in pressure lead to differential settlements in the dam (Szostak-Chrzanowski \& Massiéra, 2006).
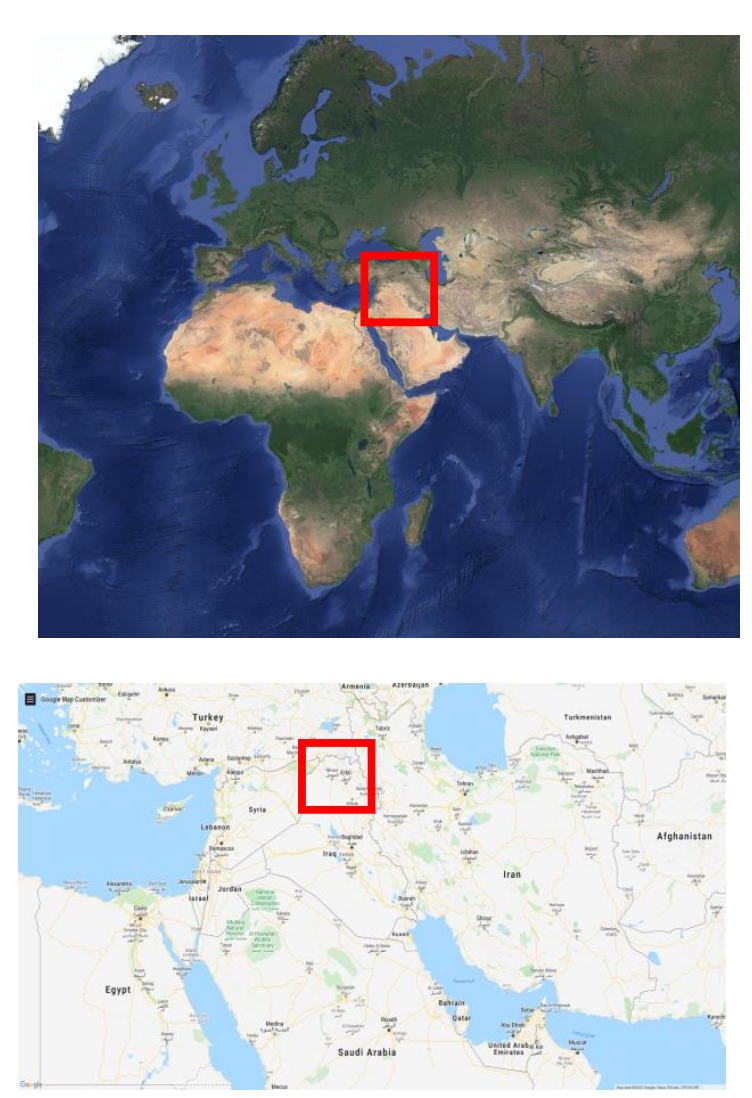

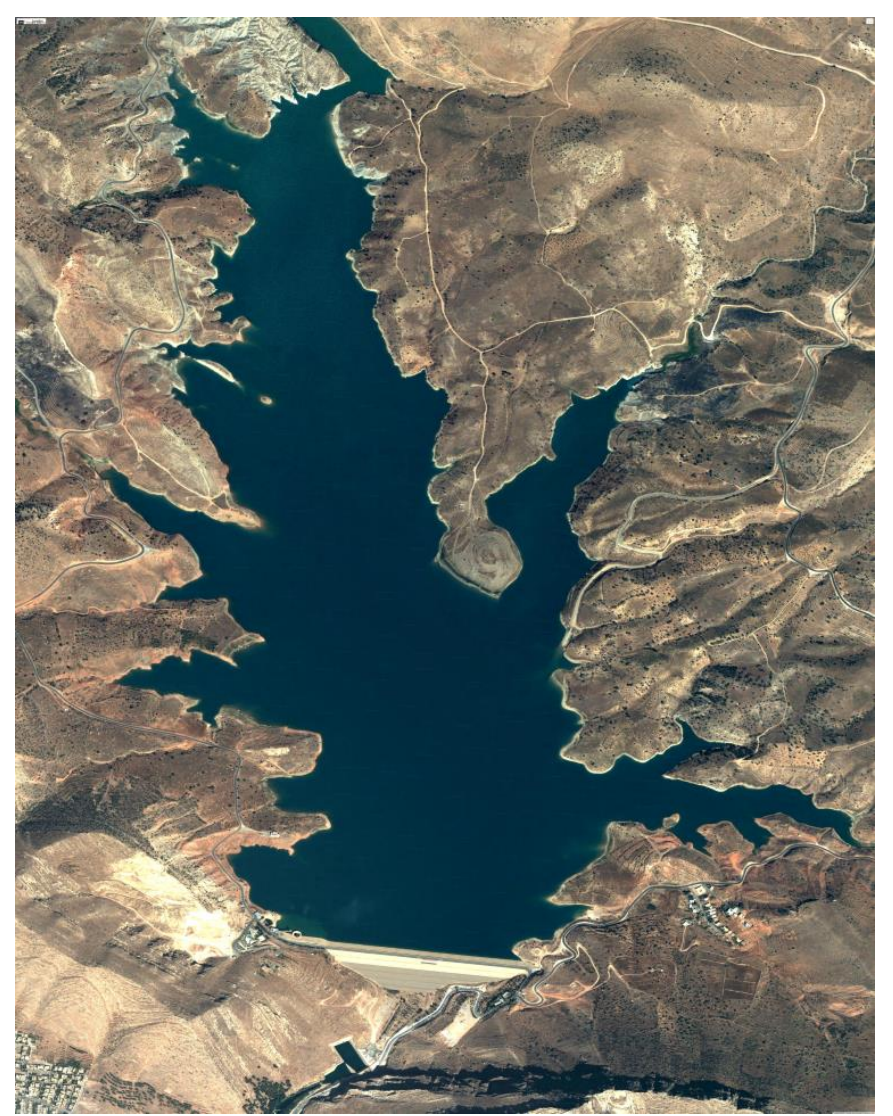

Figure 1 Duhok dam location

\section{DETERMINATION OF VERTICAL MOVEMENTS}

\section{SETTLEMENT BY GEODETIC MEASUREMENTS}

There are significant vertical displacements in the Duhok dam's fill material and the foundation due to its huge embankment composition. The methodology for geodetic dam monitoring has relied on the administration of the feasible deformation of the crest and the major axis of the dam. The procedure of this study is focused on the measurement of the elevation of multiple object points (i.e., monitoring points) at various periods. Zero measure or reference measure data were collected in 1988 by (Pakistani global engineering company cooperation with General Authority of Survey in Iraq). After that, four-period measurements were taken for vertical control in March 1990, June 1999, March 2017, and February 2019. 
The first two period measurements were collected with the precise level (Wild N3), and the other-period measurements were collected using the precise digital level (DNA 03). Throughout the construction process and the stage of the reservoir's initial filling, deformation grew rapidly as predicted, then decreased slowly with time. Vertical displacement control program depends on precise levelling measurements.

Precise measurements of geometric levelling are carried from only one reference station (DD10) established around $400 \mathrm{~m}$ away from the centre of the dam having a local coordinate system, shown in figure 2. Twenty-six monitoring points measured that are spread in three layers on the downstream of the dam, benchmarks are numbered from 1 to 27 but the benchmark 15 is missing, it has been damaged and has not been involved in measurement. Hence, 26 benchmarks are remaining, all points illustrated in figure 2. Precise digital level (DNA 03) with invar rod was used to measure vertical displacements of monitoring points. According to the accuracy claimed by the manufacturer, Leica DNA03 precise digital level has an accuracy of $0.3 \mathrm{~mm}$ per $\mathrm{km}$ with double run measurement using invar staff. The reason for using only one reference point is due to the damage of several control stations, although some stations are still in excellent condition, their data are missing hence, they cannot be included in this study.

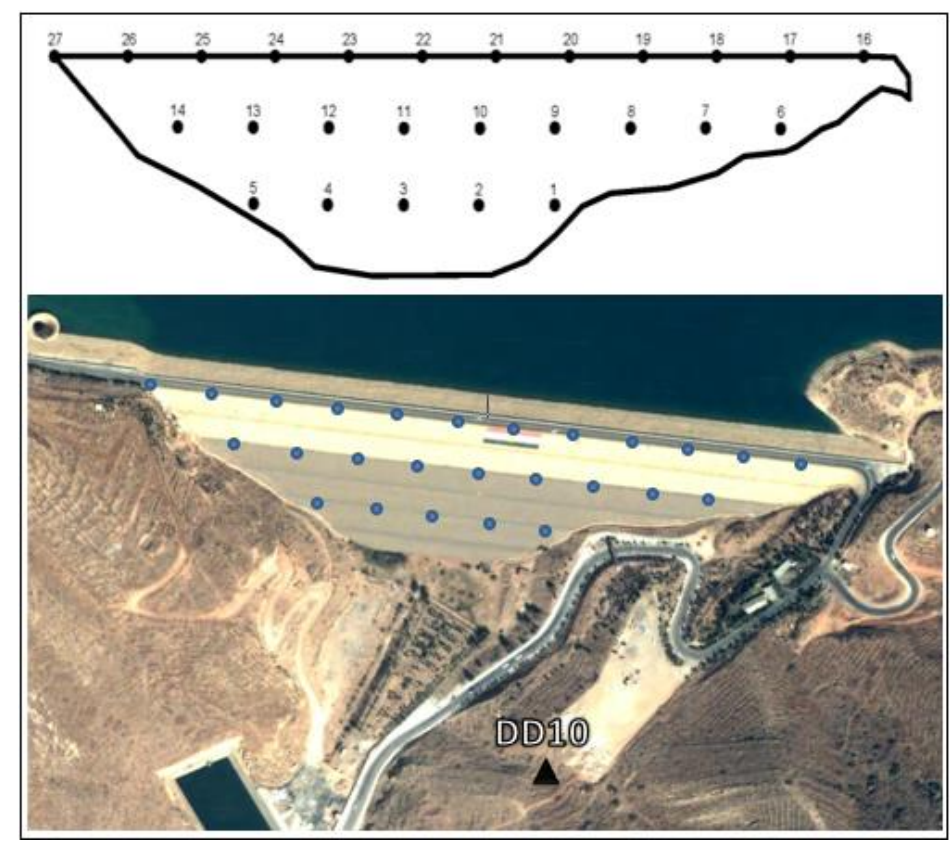

Figure 2 object points at the downstream of Duhok dam 
The 2019 campaign was carried out with three loops, the first loop started and ended from the reference point DD10 to the crest layer of monitoring points of BM16 to BM27 including the lower layer of object points of BM1 to BM5. The overall looping distance was about $1.6 \mathrm{~km}$ with a closure error of roughly $-9 \mathrm{~mm}$. The second loop started and ended from DD10 to the crest layer with the middle layer of BM6 to BM14 with the total looping distance of nearly 2.0 $\mathrm{km}$ with closure error of roughly $-5 \mathrm{~mm}$. The last loop started and ended from DD10 to the middle with the lower layer of observing points and the total looping distance of nearly $1.1 \mathrm{~km}$ with closure error of roughly $-5 \mathrm{~mm}$ as shown in figure 3 .

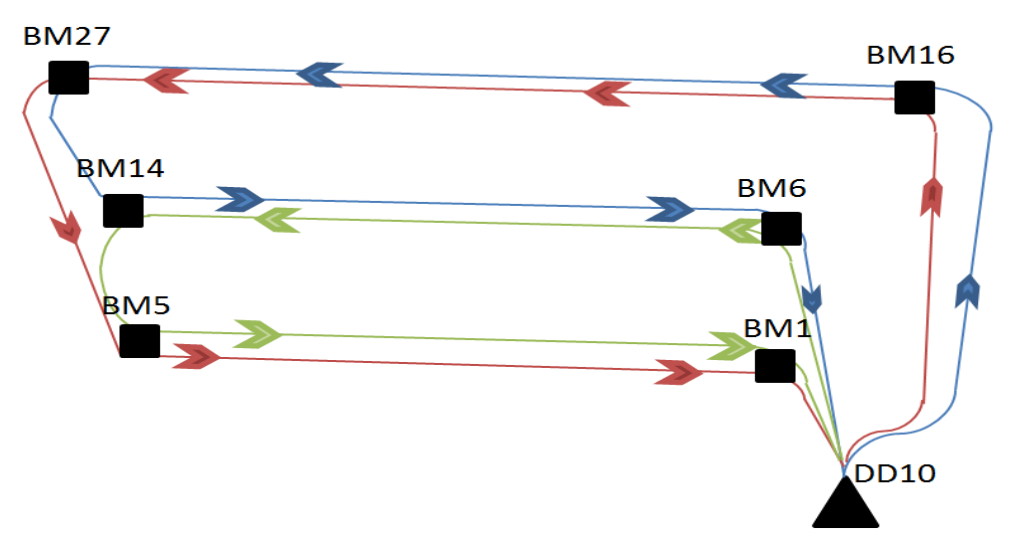

Figure 3 diagram of observation loops

\section{ADJUSTMENT OF LEVELING NETWORK}

Differential levelling measurements are used to evaluate the variances in elevations within the monitoring points in the levelling network. As with all survey measurements, adjustment of differential levelling error using the least square method can be applied to these monitoring points that dominated by random or accidental errors. The authors of this study utilized a program coded in Matlab by (Tang, 2020) the program performs the levelling error adjustment by using the least square technique. The results are calculated and the outcome of the least squares adjustment were $0.2427 \mathrm{~mm}^{2}$ for the sum of the weighted squares of residuals.

\section{PREDICTION OF SETTLEMENT}

Several predictive methods of post-construction deformation behaviour have developed empirical relationships for settlement estimation. Most of them are basic relationships of 
logarithmic or power-type depending on one or two variables. The authors used three methods in this study which are based on dam height. One of the relations that are most noticeable is that proposed by Clements and Ronald (1984). The researcher studied the settlement behaviour of crest of 68 rockfill dams in his study then he suggested this equation (1):

$$
S=\beta H^{\delta}
$$

Where $\mathrm{S}$ is settlement in (m), $\mathrm{H}$ is dam height in (m), and $\beta$ and $\delta$ are constant

The second method suggested by Lawton and Lester (1964) expressed below in equation (2):

$$
S=0.001 H^{3 / 2}
$$

The last method have been proposed by Charles (1986) who proposed the settlement index (SI) as presented in equation (3):

$$
S_{I}=\frac{s}{1000 * H * \log \left(t_{2} / t_{1}\right)}
$$

Where SI is settlement index (dimensionless), $\mathrm{s}$ is crest settlement in (mm) measured between $\mathrm{t} 1$ and $\mathrm{t} 2$ are time after completion of the structure, $\mathrm{H}$ is dam height in (m). According to Tedd, Charles, Holton, and Robertshaw (1997) if the amount of settlement index is greater than 0.02, the crest settlement is attributed to mechanisms other than creeping which require more investigations.

\section{ANALYSIS OF THE DATA}

The outcomes of geodetic monitoring over 31 years duration beginning in 1988 show the behaviour of movements in the dam. The settlement magnitude was different for the monitoring points along the crest, while the largest of the displacement is taken place at the downstream side close to the centre of the dam. This study found that the maximum of 20.4 cm settlement for all the measurements accomplished over that period.

Figure 4 illustrates the progression of the vertical displacements of the object point BM24 located at the centre of the crest and of the object point BM17 located at the tail end (east side) of the crest for the entire period of 31-year. The duration involves the post-construction and 
initial storing stages of the dam and most of its operational lifetime. From the mentioned graph, two circumstances are instantly apparent: first, the deformations cumulate over time but approach their final values; second, the settlement in the middle of the dam is much larger than the settlement observed near the crest's tail ends 20.4 and $3.97 \mathrm{~cm}$, respectively. As literature suggested Gikas and Sakellariou (2008), it can be concluded from this graph that the maximum displacement is located in the middle of the crest.

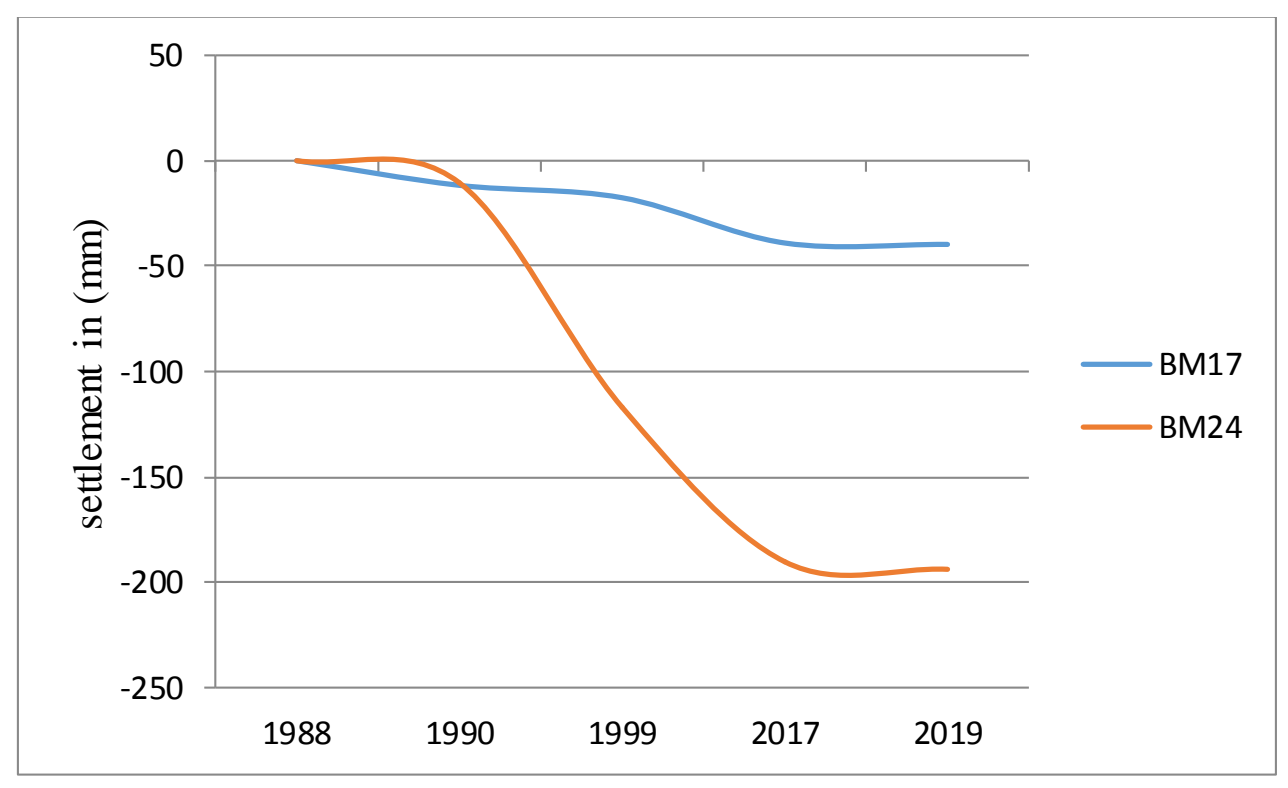

Figure 4 vertical displacements at point BM24 and BM17

Figure 5 shows the settlement of the crest's reservoir along the centerline (downstream side). The graph presents five profiles for comparison against the assumed baseline or zero motion in 1988. Each profile had a total of 12 monitoring or object points. The plot shows long-term results over the 31-year duration in 1988, 1990, 1999, 2017 and 2019. The largest settlement of $20.4 \mathrm{~cm}$ can be noticed at the object point BM24. 


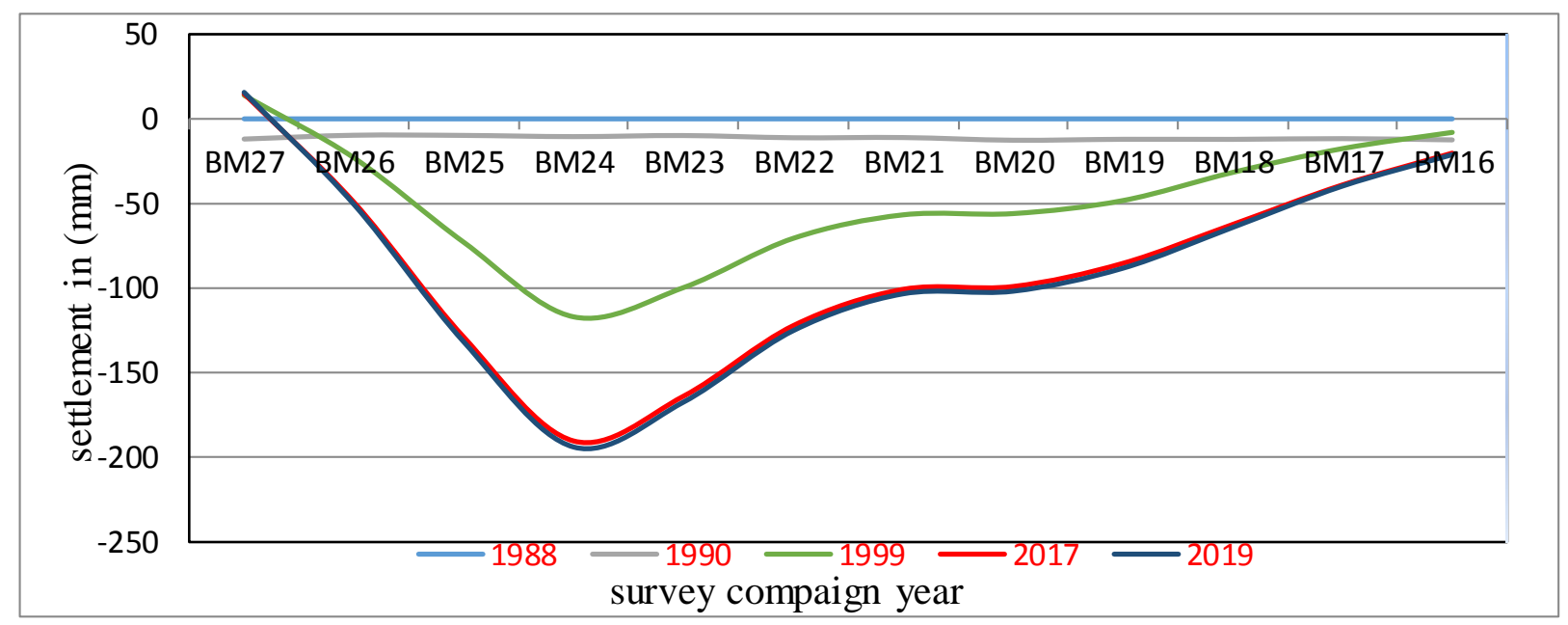

Figure 5 settlement of crest object points from 1988 till 2019

For object point BM27 throughout 31-year, it can be recognised that the displacement is found to be about $1.5 \mathrm{~cm}$ upward. The reason for this upward displacement is because of the point location since is not located on the reservoir body. The other reason for the vertical movement can be connected to the growth of the tree's roots that were located around $1.5 \mathrm{~m}$ near that point as shown in figure 6 . The tree's roots can produce upward motion as the literature suggested Isioye and Musa (2007).

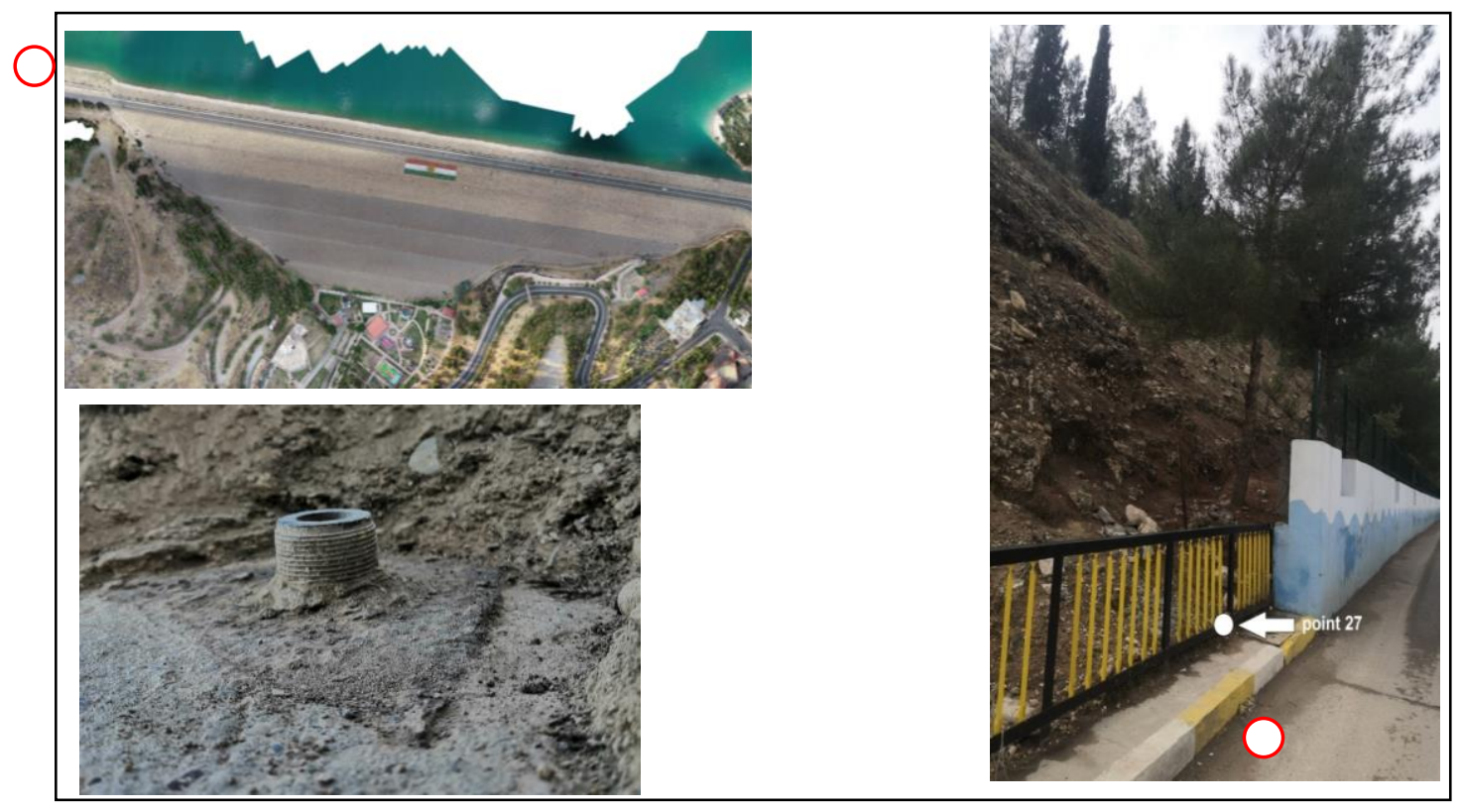

Figure 6: a layout showing the location of point BM27 
In figure 7, the actual crest settlement is plotted with predicted settlement by using Clements's equation (1) and Lawton and Lester equation (2). The results show that the predicted values by Clements are close to actual values. Most of object points have less settlement than predicted values except points (BM24 and BM25). On the other hand, predicted settlement by Lawton and Lester equation has greater values than Clements method for all object points. From this comparison it can be understood that, the Duhok dam is not at risk because the actual settlement is less than predicted settlement. The maximum settlement observed at object point (BM24) corresponds to $0.34 \%$ of the dam height from the foundation.

Anumber of researches have proposed threshold values below which the settlement as a percentage of the dam height is considered to be normal. Sowers (1965) propose the range $0.25-1 \%$. While, Dascal and Oscar (1987) gives a $0.35 \%$ threshold value. Stapledon, MacGregor, Bell, and Fell (2005) suggested a range between $0.1 \%$ and $0.4 \%$ of the dam height. According to literatures, Duhok dam is safe and there is no concern for the structural integrity of the dam.

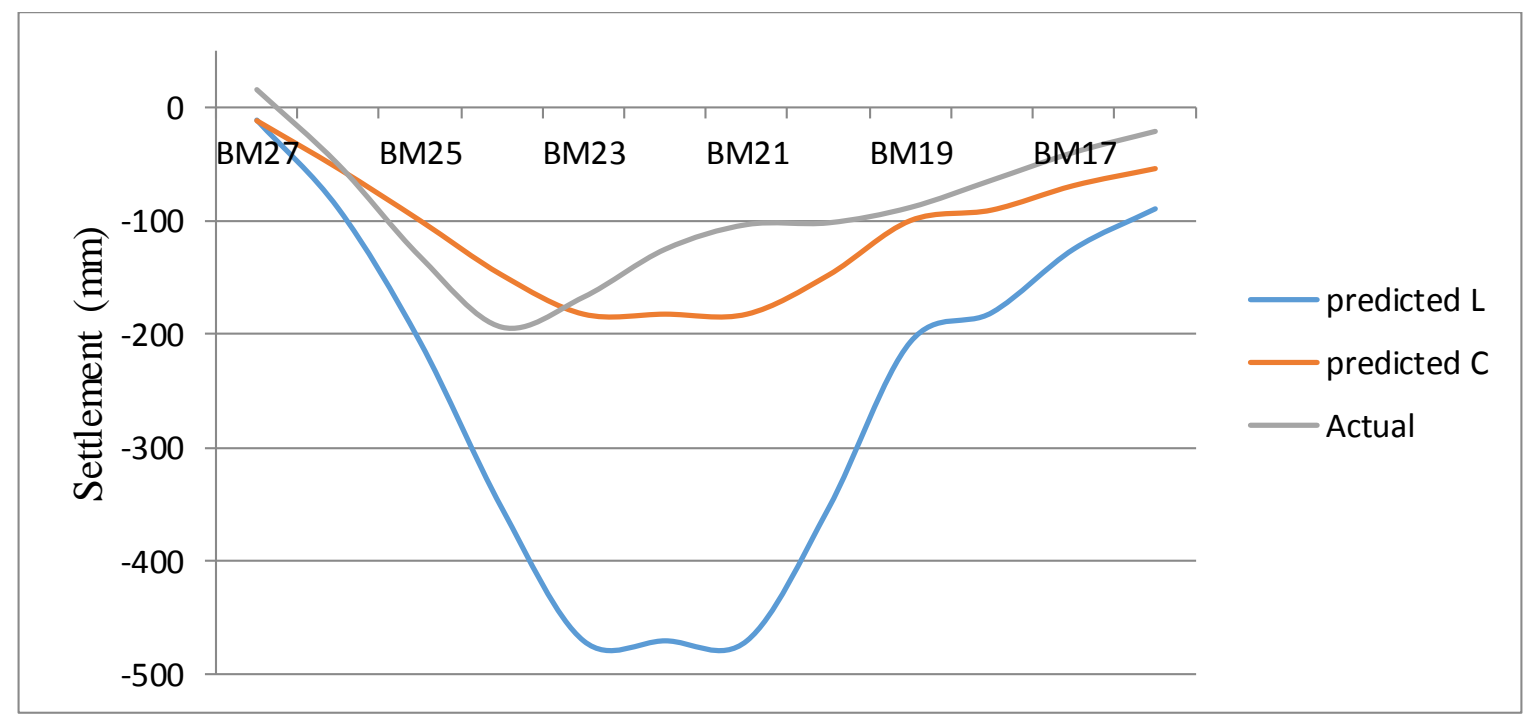

Figure 7 comparison between actual and predicted settlement

The authors of this article calculated the crest settlement index using equation (3). From figure 8 , it can be seen that till now, the settlement index has not exceeded the threshold value of 0.02 suggested by Dascal and Oscar (1987). This is another indication showing the Duhok dam's safety. 


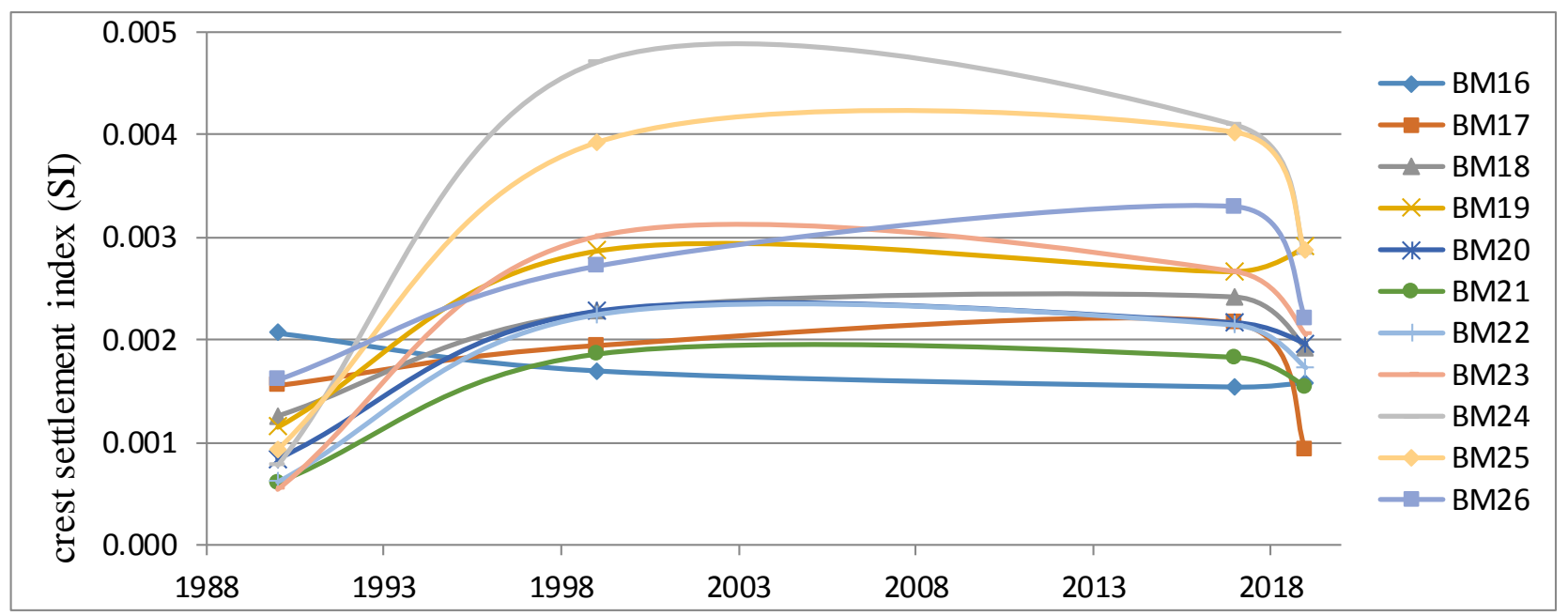

Figure 8 settlement index from 1990 to 2019

\section{CONCLUSION}

Duhok dam was built as the fundamental construction of a multi-function engineering project as water supply and for irrigation purposes. Therefore, to assure the most reliable safety practice of the reservoir, exceptional consideration has been invested in deformation monitoring of its performance. Survey measurement techniques determined distinct point's deformation at a high level of certainty comparative to a stable reference point (DD10) outside the dam itself. Survey results are employed to decide whether the displacement of monitoring points exceeds the certain limit values recommended for a similar structure worldwide.

This study included precise measurements technique conducted between 1988 and 2019 using precise levelling for the deformation monitoring of the Duhok dam. Movement's quantities over time were calculated for all target points spread on the embankment surface

of the structure. The largest settlement was found to be $20.4 \mathrm{~cm}$ for the object point BM24.

The safety of Duhok dam is checked by empirical models of prediction the settlement and threshold values of the settlement, as a percentage of the dam's height. The results showed that the Duhok dam is considered as a safe structure, and the last two survey campaign shows very small amount of displacement, indicating that there is no concern for the structural integrity of the dam.

To conclude, this study suggests that a large structure such as the Duhok dam requires observing its monitoring object on the annual bases. It is also recommended that more 
techniques such as GPS invest to enhance the efficiency of the dam deformation monitoring. Also, calculating annual rate of settlement and settlement index and comparing them with observed measurement to detect any defect on time for further investigation.

\section{REFERENCES}

Çelik, R., Ayan, T., Denli, H., Ozludemir, T., Erol, S., Ozoner, B., .. . Groten, E. (2001). Monitoring Deformation on Karasu Viaduct Using Gps \& Precise Leveling Techniques. In Strong Motion Instrumentation for Civil Engineering Structures (pp. 407-415): Springer.

Charles, J. (1986). The significance of problems and remedial works at British earth dams. Paper presented at the Proceedings of BNCOLD/IWES Conference on Reservoirs.

Clements, \& Ronald, P. (1984). Post-construction deformation of rockfill dams. Journal of Geotechnical Engineering, 110(7), 821-840.

Dascal, \& Oscar. (1987). Postconstruction deformations of rockfill dams. Journal of Geotechnical Engineering, 113(1), 46-59.

Emadali, L., Motagh, M., \& Haghighi, M. H. (2017). Characterizing post-construction settlement of the Masjed-Soleyman embankment dam, Southwest Iran, using TerraSAR-X SpotLight radar imagery. Engineering structures, 143, 261-273. doi:https://doi.org/10.1016/j.engstruct.2017.04.009

Engineers, U. A. C. o. (2002). Structural Deformation Surveying (EM 1110-2-1009 ed.). US Army Corps of Engineers, Washington, DC.

Featherstone, W. E., Dentith, M. C., \& Kirby, J. F. (1998). Strategies for the accurate determination of orthometric heights from GPS. Survey review, 34(267), 278-296.

Gikas, V., \& Sakellariou, M. (2008). Settlement analysis of the Mornos earth dam (Greece): Evidence from numerical modeling and geodetic monitoring. Engineering structures, 30(11), 3074-3081.

Gökalp, E., \& Taşçı, L. (2009). Deformation monitoring by GPS at embankment dams and deformation analysis. Survey review, 41(311), 86-102.

Guler, G., Kilic, H., Hosbas, G., \& Ozaydin, K. (2006). Evaluation of the movements of the 
dam embankments by means of geodetic and geotechnical methods. Journal of surveying engineering, 132(1), 31-39.

ICOLD (Producer). (Nov 27, 2019). General Synthesis. Retrieved from http://www.icoldcigb.net/GB/world_register/general_synthesis.asp

Isioye, O., \& Musa, A. (2007). The Use of Geodetic Leveling For Crustal Motion and Deformation Studies: A 30-Year Case Study in Ahmadu Bello University, Zaria. Information Manager (The), 7(2), 28-39.

Kalkan, Y., Potts, L. V., \& Bilgi, S. (2016). Assessment of vertical deformation of the atatürk dam using geodetic observations. Journal of surveying engineering, 142(2), 04015011.

Lawton, F. L., \& Lester, M. D. (1964). Settlement of Rockfill Dams. Eighth International Congress on Large Dams, held at Edinburgh,Scotland, 3, pp. 599-613.

Michalis, P., Pytharouli, S., \& Raftopoulos, S. (2016). Long-term deformation patterns of earth-fill dams based on geodetic monitoring data: The Pournari I Dam case study. Paper presented at the Proceedings of the 3rd Joint International Symposium on Deformation Monitoring (JISDM), Vienna, Austria.

Richardus, G. (1977). Project Surveying. North Holland Publishing Co, Amsterdam, New York.

Sowers, G. (1965). Compressibility of broken rock and the settlement of rockfills. Paper presented at the Proceedings of the 6th International Conference on Soil Mechanics and Foundation Engineering, Montreal, Canada.

Stapledon, D., MacGregor, P., Bell, G., \& Fell, R. J. T. o. t. A. (2005). Geotechnical engineering of dams. $20,99$.

Szostak-Chrzanowski, A., \& Massiéra, M. (2006). Relation between monitoring and design aspects of large earth dams. Paper presented at the Proceedings, 3rd IAG Symposium on Geodesy for Geotechnical and Structural Engineering and 12th FIG Symposium on Deformation Measurements. Baden, Austria.

Tang, r. (2020). The Program for Leveling Network adjust using least square Retrieved from (https://www.mathworks.com/matlabcentral/fileexchange/37042-the-program-for-leveling- 
network-adjust-using-least-square)

Taşçi, L. (2008). Dam deformation measurements with GPS. Geodezija ir kartografija, 34(4), 116-121.

Tedd, P., Charles, C., Holton, I., \& Robertshaw, A. J. G. (1997). The effect of reservoir drawdown and long-term consolidation on the deformation of old embankment dams. 47(1), 33-48.

Tovî, M., \& Șālih, K. (2017). Însiklopîdîya parêzgeha Dihokê. Duhok - Iraq.

Verdonck, D. (2004). Determination of Vertical Surface Deformation From Repeated Historical Leveling in Cascadia. AGUSM, 2004, G21A-03.

Wang, T., Perissin, D., Rocca, F., \& Liao, M.-S. (2011). Three Gorges Dam stability monitoring with time-series InSAR image analysis. Science China Earth Sciences, 54(5), 720732. 